\title{
Dreams and Nightmares of Liberal International Law: Capitalist Accumulation, Natural Rights and State Hegemony
}

\author{
Tarik Kochi ${ }^{1}$
}

Published online: 1 July 2016

(C) The Author(s) 2016. This article is published with open access at Springerlink.com

\begin{abstract}
This article develops a line of theorising the relationship between peace, war and commerce and does so via conceptualising global juridical relations as a site of contestation over questions of economic and social justice. By sketching aspects of a historical interaction between capitalist accumulation, natural rights and state hegemony, the article offers a critical account of the limits of liberal international law, and attempts to recover some ground for thinking about the emancipatory potential of international law more generally.
\end{abstract}

Keywords Capital · Grotius · Hegemony · International law · Legal theory · Liberalism · Natural rights · Political economy · Primitive accumulation · Terrorism · War

\section{Introduction}

One aspect of the dream of liberal international law which emerges at least from the seventeenth century is the idea that modern commerce can help to move the world towards peaceful international relations. This idea is expressed in seventeenthcentury theories of natural rights and is later inherited and developed in eighteenthcentury classical political economy and in liberal political theory in the nineteenth and twentieth centuries. The idea has not been without its many critics. For example, for Lenin, intra-capitalist economic competition in the late nineteenth and early twentieth century was seen as a major cause of violent imperialism and interstate war (Lenin 1987). For Immanuel Wallerstein, the shaping of a modern capitalist world system has come about historically through interstate violence as

Tarik Kochi

t.kochi@sussex.ac.uk

1 Sussex Law School, School of Law, Politics and Sociology, University of Sussex, Brighton BN1 9SP, UK 
great powers jostle to gain a position of hegemonic dominance over the global economy (Wallerstein 2004). The idea of global liberal peace has been portrayed then as both a beautiful dream and as a horrific nightmare. ${ }^{1}$

By focussing upon the relation between commerce, peace and war, this article sketches an outline of the conceptual architecture of the modern tradition of 'liberal international law'. I argue that one way of understanding the modern question of war and peace, and its relationship to commerce, is to conceptualise the framework of liberal international law as an interplay between at least three dominant elements. These are: capitalist accumulation, natural rights, and state hegemony. In what follows I outline a number of important ways in which these three elements can be seen to run together and form the juridical and political glue which holds together the tenuous shreds of fabric that constitute the modern liberal world order. In this respect the account developed offers a contribution to thinking about, and problematising, the relationship between modern international law, global commerce, and the liberal peace thesis. By interpreting the tradition of liberal international law through such a lens the liberal dream of global peace is shown to bob about erratically upon a sea of anger and nightmares.

As a point of note, the account that follows presents the 'bare bones' of a set of arguments developed in a wider project. As such the article sketches a number of lines of historical and genealogical inheritance and involves the limitation of skipping over historical specificity at certain points. While I appreciate that this undermines the account in some respects, I hope that at least what is gained is the drawing of attention to an interaction between a juridical discourse (natural rights), a form of political economy (capitalist accumulation), and modes of political organisation (class power, state hegemony). The intention is to offer an account of modern international law in which these three elements play an important role, mutually constituting, and reinforcing each other.

Such an account has the benefit of resisting 'economic determinist' critiques of international law in which all juridical and political relations and all forms of normativity are reduced to an economic mode of production, and in which international law is condemned as merely the expression of 'capitalist imperialism'. In this respect the account offers an alternative mode of 'left critique' than that offered by the 'commodity-form theory of international law' as developed by Pashukanis (1978) and popularised by Miéville (2006). In doing so I hope to develop a critique of the modern form of liberal international law, while at the same time being able to hold onto the emancipatory potential of international law via, albeit briefly, highlighting its inheritance of the traditions of radical natural law and radical republican constitutionalism. Remembering that international law inherits at least aspects of these traditions helps us to conceptualise global juridical relations as a site of contestation over questions of social and economic justice. Within this, ongoing normative claims about justice, human dignity, equality and democracy present a variety of counter-hegemonic discourses aimed at reorganising and marshalling global political economy. Even when confined to the margins, the

\footnotetext{
${ }^{1}$ For critical accounts of the idea of liberal peace see Hardt and Negri (2001), Dillon and Reid (2009), Jahn (2013), Fine (2007).
} 
endless presence of counter-hegemonic international legal discourses, which often demand the rendering as public what has previously been rendered as private, operate as a potential, enduring nightmare for liberal international law.

\section{Commerce and Global Peace}

One key set of texts which outline a distinctly 'liberal', cosmopolitan vision of international law and international relations are Immanuel Kant's writings on questions of war and peace developed at the end of the eighteenth century (Kant 1991). Kant's idea of an international federation of states grouped together to protect global peace and safeguard cosmopolitan human rights have been interpreted as a founding utopian theory that underlies nineteenth- and twentiethcentury attempts to develop a global, liberal form of international law. ${ }^{2}$ Central to Kant's account is an Enlightenment optimism that the economic relations of modern commerce will draw states into closer ties of mutual dependency and through this towards global peace. Kant argued:

For the spirit of commerce sooner or later takes hold of every people, and it cannot exist side by side with war. (Kant 1991, pp. 114 and 44-46, 50-53)

Within such an optimistic view Kant noted a degree of paradox contained in this operation whereby the selfish and unsocial actions of private property owners could produce a positive degree of social utility as well as social and historical progress. In this respect, modern commerce, for Kant, was characterised by an 'unsocial sociability' (Kant 1991, p. 44). In expressing this idea Kant was echoing an earlier formulation developed by Pufendorf (2003, pp. 52-56), Locke (1988, pp. 294, 297), Hume (1994, pp. 97-102) and Smith (2007, pp. 215-216). ${ }^{3}$

Within the long history of the natural law tradition there have been a number of accounts which express conceptual linkages between the idea of peace, lawful relations between neighbours and states, and the beneficial social utility of private property, commerce and trade. Aspects of this idea can be found scattered through Aristotelian philosophy (Aristotle 2001, 1.9, pp. 1138-1140) and middle to late Stoic philosophy (Erskine 2011; Brunt 2013), Roman law (Jolowicz and Nichols 1972, pp. 104-105), Ciceronian ethics (Cicero 1991, pp. 9, 14-15), and medieval and early modern Scholastic philosophy, such as that developed by Francisco de Vitoria (Vitoria 1991, pp. 278-280; Koskenniemi 2011a, b). Elements of this linkage had begun to be conceptualised through a subjective natural rights language which had developed in Europe as early as the twelfth century (Tierney 2001), and at least by the fourteenth and fifteenth centuries (Tuck 1981; Villey 2000). It was however in the early seventeenth century, in the work of Grotius (2005), that a distinct theory of commercial natural rights came to be expressed in a way that

\footnotetext{
${ }^{2}$ For various Kantian accounts see generally Rawls (1993), Bohman and Lutz-Bachman (1997), Held (1995), Doyle (1983).

3 On the question of 'unsocial sociability' see more generally Hont (2005), Haakonssen (1996).
} 
outlined the core conceptual structure of the modern, liberal idea of international law in the way that we understand it today.

Grotius's theory of natural rights and international law performed a number of important conceptual innovations. His account secularised the idea of natural rights (Grotius 2005, p. 89; Somos 2011) and developed a theory of sovereignty grounded upon the priority of individual natural rights ('preservation of life') and rights to private property. Sovereign power gained its legitimation through the maintenance of these under conditions of social peace ('peaceful sociability') (Grotius 2005, pp. 180-187, 93-94, 184; Tuck 1993). Grotius also developed an economic theory of the derivation of the right to private property. This took place not simply through 'original occupation' and inter-subjective 'consent' (Grotius 2005, pp. 420-427), but also through the operation of 'natural necessity' (Grotius 2005, pp. 154, 184-186). In this, Grotius argued that the desire for improvement, and the operation of labour and mutual exchange, justify through 'natural reason' and social 'progress' the validity of private property rights (Grotius 2005, pp. 154, 184-186; Garnsey 2007, p. 139) — an idea which is later more fully developed within Locke's labour theory of property (Locke 1988, pp. 287-288). Tied to this Grotius reframed international law as a normative relationship between not only states, but between private property owners (Grotius 2005, pp. 189, 198, 393-397). Here global legal relations express an idea of free trade and limited monopolisation (Grotius 2005, pp. 452-453), and through the notion of the 'just war' (Grotius 2005, pp. 180, 397-398, 416-417), and right of 'punishment' (Grotius 2005, pp. 1018-1021) states (and private actors such as trading companies) are granted a right of selfenforcement to protect universal private property rights and natural rights through violence (Grotius 2004, p. 58; Tuck 1999; Van Ittersum and Julia 2006).

Subsequent lineages of natural rights and liberal thought have built on this conceptual structure outlined by Grotius. This has involved the attempt to reconcile a tension between, on the one hand, economic utility and social progress contained within commercial relations and, on the other, the unsocial consequences of commerce, in which selfishness and economic competition manifest in open war and violence. For example in the eighteenth century both David Hume and Adam Smith saw a danger in a 'jealousy of trade' in which states adopted mercantilist policies and used war as a means of enabling and protecting capital accumulation. Both argued that states should recognise the mutual advantages of trade and the shared flourishing and progress that takes place through the free and open exchange of commerce (Hume 1994, pp. 150-151; Smith 1999b, p. 72).

Such an outlook involved thinking of competing states, not in terms of enmity and threat, but as economic competitors within the broader field of a global geographical or spatial division of labour, whose unsocial material self-interest (desire for opulence, the accumulation of wealth), when carried out peacefully, could produce a positive social result (Hill 2010; Kingsbury and Straumann 2010). In the late eighteenth century this line of liberal thinking was reconceptualised as needing an institutional framework, whereby for thinkers like Kant and Jeremy Bentham the goal of pacifying global commerce was seen to necessitate the formation of an international federation of states to act as a mediator and arbitrator of interstate disputes (Kant 1991; Bentham 1843). 
However, one lineage of the liberal tradition which is often underemphasised is a particular interpretation of aspects of Adam Smith's thought which are, in many important ways, 'anti-cosmopolitan' and emphasise the unsocial nature of global commerce. ${ }^{4}$ On such a reading, Smith locates the state as the primary vehicle that secures individual liberty and argues that the goal of nationally-orientated wealth accumulation will often trump cosmopolitan arguments that favour global free trade (Smith 2007, pp. 272-273, 269-271). ${ }^{5}$ For Smith an ethic of 'love of country' forms a stronger sentiment than a more distant 'love of humanity' (Smith 2007, pp. 267-276). Combined with this is Smith's historical sociology which saw an important link between the state's ability to finance the ever-growing technology of warfare and the privileging of national merchants who generate wealth and offer credit to the state (Smith 1999b, pp. 279-297, 304-305, 411). Hence, in an era marked by dynastic and mercantilist conflict, colonisation and empire, Smith argued that the goal of maintaining the positive fortune of the home nation meant a form of statecraft that often drew upon protectionist techniques. For Smith this did not morally justify aggressive policies of imperialism (Smith 1999b, pp. 25, 142) but did, for example, involve forms of economic warfare such as the Navigation Acts (1651-1849), aimed initially at countering the threat to England by the rise of Dutch commercial and naval hegemony (Smith 1999b, pp. 40-41).

In this respect Smith's theory of political economy can be interpreted as expressing a governance technique that flips between strategies of openness and closure, between encouraging free markets, and the protecting of home markets. This governance technique of openness/closure draws as much upon Grotius' mare liberum, as it does upon John Selden's mare clausum. ${ }^{6}$ As such, Smith's approach highlights a tension within liberalism and the liberal tradition of international law which is characterised by competing ethical demands between a 'love of country' and a 'love of humanity' (Nussbaum 2002). Such a tension is further problematised by Smith when he speaks of the commercial interests of a set of merchants and financiers as being in conflict with what he deems to be the 'national interest'. This is a problem for Smith especially in cases where national economic policy is shaped to benefit only a narrow set of merchant and banking interests (Smith 1999b, pp. 48-49, 409; Arrighi 2007). Viewed in this light, unsocial commercial sentiment offers, in the least, something of an unstable footing from which to develop a goal of global, liberal peace.

\section{Commerce and Global War}

Aspects of this tension between commercial sociability, and warlike unsociability can be seen to have played out in nineteenth-century and early twentieth-century international relations. In the nineteenth century the industrial revolution in Britain

\footnotetext{
4 Aspects of this account can be found in Hont (2005), Wyatt-Walter (1996).

5 Smith argued: '(T)he great object of the political economy of every country is to increase the riches and power of that country' (Smith 1999a, p. 472).

${ }^{6}$ On this relation see generally Selden (1652), Armitage (2000), Somos (2012).
} 
and then in Western Europe and North America prompted a massive expansion in the global capitalist economy and in the volume of world trade and global finance (Hobsbawm 1977, 1997). This expansion was celebrated and promoted through theories of laissez-faire economic liberalism in which British 'free trade' policy reflected and championed globally many of the core elements of natural rights thinking. The period of limited conflict between Western powers between 1815 and 1914 is sometimes viewed as an example of the empirical link between commerce, liberal political principles and peace (Polanyi 2001, p. 5).

However the expansion of nineteenth-century capitalism walked hand in hand with a rabid increase of European and North American colonial and imperial violence involving the carving up of territory, the subjection of supposedly 'uncivilised peoples', and the forced opening of markets through gunboat diplomacy and war (Hobsbawm 1994; Said 1978). For Karl Marx, nineteenth-century industrial capitalism, expressed through the secular religion and ideology of liberal natural rights and economic utilitarianism (Marx 1990, p. 280), combined the economic exploitation of wage labour in Britain with violent forms of "primitive accumulation' through the expansion of colonies abroad (Marx 1990, pp. 931-940). In this, British free trade ideology often functioned as 'free trade imperialism', backed by violence and set against more protectionist and state-directed modes of capitalist development such as undertaken in nineteenth-century Prussia (Chang 2003). By 1914 inter-capitalist, unsocial state competition combined with conflicting imperial claims, dynastic conflict, economic crisis, and ideological extremism led to a period of 30 years of global wars and instability lasting until 1945 (Hobsbawm 1994). In this period the liberal discourse of international law, either through the 'balance of powers' system, or through the League of Nations, proved ineffective at reconciling the tensions between commerce and war (Polanyi 2001, pp. 21-32).

In this light John Hobson's and Lenin's theories of capitalist imperialism and intra-capitalist war echo a number of key aspects identified earlier within Smith's critique of mercantilism and his highlighting of the problem of the unsociability of inter-state commerce. For Hobson and Lenin state-orientated capitalist development was linked to monopolisation and imperialism where states used violence to secure monopolies over overseas markets and raw materials and to protect home industries from foreign threats in the name of self-defence and national security (Hobson 2011; Lenin 1987). For Lenin class power exerted by industrial and financial capitalist interests over their home nations drove state policy in an expansionist, imperial direction and in 1914 brought imperialist, capitalist states directly into conflict with one another in the form of global war (Lenin 1987, pp. 226-45). For Lenin also, such a focus upon inter-state war masked a longer, ongoing form of violent 'class struggle' sitting within and beneath international relations. Capitalist class violence launched through the security apparatus of the state, and proletarian, political revolution in response to this, constituted then broadly a form of 'violence' in which rival class interests fought over the political means of instituting competing ideas of social and economic justice. Such a political reality demanded the reconceptualisation of the concept of 'war' as transnational 'class war' (Kochi 2009, pp. 196-202). 
Building upon this, though criticising aspects of Lenin's account, Karl Polanyi presented a line of critique in which the relationship between war and nineteenthand early twentieth-century industrial and finance capitalism reflected the two competing aspects of commercial unsocial sociability expressed in Smith's theory. For Polanyi late nineteenth- and early twentieth-century finance capital played a dual role. In one sense British, European and North American financial capital played a diplomatic role in pacifying global commerce and trade and holding together the balance of powers system (Polanyi 2001, pp. 10-20). In this, finance capital saw major wars between great powers as a threat to profitability through the shrinking of trade and capital investment between belligerents. Yet finance capital benefited from and promoted a multitude of nineteenth- and twentieth-century wars of colonial and imperial expansion, and viewed as profitable regional conflicts between developing states. In this respect, Anglo-European finance capital promoted small and regionally contained colonial wars as they opened markets, opportunities for investment, and generated profits within the armaments industry (Polanyi 2001, pp. 10-20). However, for Polanyi these two 'peaceful' and 'violent' aspects of commercial 'unsocial sociability' proved to be irreconcilable between 1914 and 1945 where global finance capital was unable to prevent the breakdown of nineteenth-century liberal Anglo-European civilisation (Polanyi 2001, pp. 21-32). The warlike and aggressive nature of state-orientated capitalist accumulation brought great capitalist powers into regional and imperial conflict in 1915, and then into ideological conflict in the $1930 \mathrm{~s}$ as autarkic regional zones of capital accumulation collided (Block 1977, pp. 12-31). Under the early stages of industrial and financial globalisation in the nineteenth and early twentieth centuries the 'jealousy of trade' was intensified into a battle to control the shape and nature of global capital accumulation undertaken through industrialised, 'total war'.

\section{Hegemony and Liberal World Order}

One liberal 'solution' to the tension between commerce and interstate war was put in place institutionally from 1945 onwards through the dual mechanism of a cosmopolitan federation of states, and the hegemonic role of a dominant liberal, capitalist state. The pacification of commerce, the global coordination of capitalist accumulation, the financing of post-war economic development, the shaping of much of the institutional framework of the United Nations, and the backing of international law and global security through military force, has been held in place since 1945 through the expansion of the military, bureaucratic, political and economic power of the United States of America (Mann 2013). The liberal theorist G. John Ikenberry describes the link between the current liberal world order and American hegemony:

The pivotal moment in liberal order building occurred in the years after World War II. It was then that America's desire for a congenial world order - open, stable, friendly - turned into an agenda for the construction of a liberal hegemonic order. But this shift was not entirely deliberate. The United States 
took charge of the liberal project and then found itself creating and running an international order. America and liberal order became fused.

It was a distinctive type of order - organised around American hegemonic authority, open markets, cooperative security, multilateral solutions, social bargains, and democratic community. It was also built on core hegemonic bargains. These bargains determined how power and authority would be apportioned. So although the United States ran the liberal order and projected power, it did so within a system of rules and institutions - of commitments and restraints. It underwrote order in various regions of the world. It provided public goods related to stability and openness, and it engaged in bargaining and reciprocity with its allies and partners. The centre of gravity of this order was the West - and as it moved outward to Asia, Latin America, and the developing world, the liberal logic gave way to more traditional imperial and great-power domination. Globally, the order was hierarchical - dominated by the United States - but infused with liberal characteristics (Ikenberry 2012, p. 334).

For critical theory, and in particular for 'world systems theory', the idea of the benevolent role of the USA as a liberal hegemon which managed to reconcile the unsocial aspects of global capitalism and global peace has been viewed far more problematically. ${ }^{7}$ For Thomas McCormick the post-1945 global economic and political order underwritten by US hegemonic power combined the aim of pacifying global commercial relations with the goal of placing US industrial and financial capital at the centre of a system of global capital accumulation which the US state attempted to control and direct. For McCormick the explicit aim developed by US policy makers in the 1940s and 1950s was to create a stable and secure global system of capitalist accumulation in which US industry and finance would have access to global markets unencumbered by old European imperial preferences, socialist planned economies or postcolonial national development. Over the middle decades of the twentieth century this would be achieved through the 'carrot' of development aid and credit tied to economic and political structural reforms, and the 'stick' of open and covert wars aimed at disciplining predominantly developing states into accepting a US-directed global capitalist development model (McCormick 1995).

In many cases in the developing world, such as Vietnam in the 1960s and 1970s, and in Iraq from the 1990s to the present, the 'stick' of war has involved a brutal scorched earth policy in which American and US-funded proxy armies decimated urban and peasant populations and attempted to maintain 'international peace and security' through the terror of aerial bombardment, land invasion, and endless 'dirty wars' (Mann 2013; Chomsky 1991; Westad 2007). Such aggressive wars, often drawing upon the natural law language of the 'just war' (Douzinas 2007, pp. 236-66; Kochi 2009, pp. 23-47), can be interpreted as a modern continuation of the violence of 'primitive accumulation' in which natural resources are secured and national economies dismantled and brought firmly into the orbit of privatisation

\footnotetext{
${ }^{7}$ See generally the accounts in Braudel (1984), Wallerstein (2011a), Arrighi (1994), Amin (1997).
} 
and capitalist markets (Neocleous 2014). This violence operates also as a form of 'class war' in which economic and state resources are brought under the control of local elites supported by American capital (Robinson 1996). Such wars have also extended a degree of 'biopolitical' control over populations in both the developing world and in the West. Justified via a discourse of 'security', 'emergency' and 'state of exception' the portrayal of internal and foreign threats ('communism', 'terrorism') have been used to discipline and control populations and globally extend economic and social policies of capitalist accumulation (Agamben 1998; Hardt and Negri 2001; Douzinas 2007; Neocleous 2008; Butler 2010).

In the Cold War lasting through to the late 1980s the US policy model aimed also at financing, rebuilding and supporting the liberal economies of Western Europe, Japan and East Asia, and backing authoritarian regimes in the developing world as a bulwark against Soviet influence and against the spread of socialist and communist economic models. Through development aid, the overseas expansion of American multinational corporations, and the propping up of local elites through covert military power, the USA was able to place itself at the centre of a global capitalist economy which often entrenched a pattern of 'underdevelopment' for many parts of the developing world (McCormick 1995; Anderson 2013; Robinson 2014).

While US legal and political rhetoric preached a language of open and free markets, in practice, for the latter half of twentieth century US economic policy often maintained high levels of domestic protectionism and subsidisation for many home industries while attempting endlessly to pry open foreign markets to the advantage of US capital (Block 1977; Rist 2014). In this respect US hegemonic power utilised an economic governance technique of openness/closure as identified in Smith. From the late 1980s onwards such a governance technique of openness/closure was used by American policy makers and American financial capital through its renewed control of economic global governance organisations such as the World Bank, International Monetary Fund and World Trade Organization (Peet 2009; Pahuja 2011; Chimni 2004). Such a technique also characterises aspects of late twentieth-century capitalist development in Japan and Germany, as well as parts of East Asia and China since the 1990s, in which state coordinated economic development continually flips between emphasising free markets in some instances, and state protectionism in others (Rist 2014; Gilpin 2001).

Sitting under the rhetoric of twentieth- and twenty-first-century free market liberalism has involved then a hegemonic coordination of global capitalist accumulation by the USA attempting to balance a policy goal of global pacification with the nationalistic privileging of domestic industrial, multinational and financial capitalist interests. Framed in terms of world systems theory, US state power has assisted the development of other capitalist states (Germany, Japan, China) and then has watched as capitalist growth in these states (as well as in East and Southeast Asia, India and Brazil) has outstripped growth in the USA (Wallerstein 2004, pp. 76-91). In the early twenty-first century, on the back of a secular profitability crisis affecting the US and Western economies since the 1970s (Brenner 2006), and the 'global financial crisis' in 2008 and subsequent 'great neoliberal recession' (Mann 2013, pp. 322-360), the idea that the USA could maintain a position of 
hegemony over global capitalism has been thrown into question. Liberals like Ikenberry have projected a changed future for American hegemonic power under conditions of global political 'crisis'. This involves a recognition that with the decline of US economic predominance and the rise in economic fortunes of countries like China and India, the USA needs to play a role of attempting to bring a range of countries into the fold of the liberal world order through shared global decision making (Ikenberry 2012, pp. 348-360).

For Ikenberry, if this fails, and if the globe splits into autarkic spheres of economic and political influence and conflict, then the USA must play a continued role of defending global liberal values and preserving the existence of a less global, and more fragmented liberal order (Ikenberry 2012, pp. 348-360). For critics like Wallerstein the decline of US economic hegemony should remind us of previous moments of hegemonic breakdown and contestation such as in the late nineteenth and early twentieth centuries with the decline of British economic hegemony. In situations where a single state can no longer exert sufficient control over the capitalist world system, the jostling and advantage taken by emerging powers can lead to periods of instability, interstate war and long periods of global conflict followed by new configurations of regional and perhaps even global capital accumulation (Wallerstein 2004, pp. 76-91). Viewed in such terms the liberal utopian dream of international law, which links 'global commerce' to 'global peace', remains far from reality.

\section{Hegemony and International Law}

From the middle of the twentieth century running through to the present a specific linkage between capitalist accumulation, state hegemony and a discourse of liberal natural rights have underlain the development and operation of liberal international law. In shaping a liberal world order the juridical language of natural rights, as a liberal discourse of human rights (Douzinas 2000), and as an economic discourse of free-market capitalism, has operated as the underlying conceptual content of liberal international law (Koskenniemi 2011a, b; Pahuja 2011). For the USA, and allied liberal states, the discourse of natural rights has been posited as a universal juridical language whose 'jurisdictional' (Dorsett and McVeigh 2012) reach is viewed as potentially infinite, especially when framed in terms of questions of 'humanitarian intervention' (Orford 2007) and neoliberal economic development (Chimni 2006). Institutionally, natural rights and liberal dreams of an institutional federation of states underpinning international law, the United Nations (UN), have been set in place since 1945 primarily through the workings of US political, economic and military power. While the UN is an internationalist institution, and its various agencies have been subject to competing state interests, the USA has played a key role in guiding and shaping many central operational aspects of the UN and its sister agencies, particularly in relation to issues of 'peace and security' and 'economic development' (Kennedy 2006).

The connection between shaping the nature of an international legal order and state hegemony can be traced through a number of periods historically. Over time 
various 'great powers' have attempted to influence, direct and control the nature of international juridical relations. ${ }^{8}$ However, from the perspective of world systems theory, as framed by Wallerstein, the idea of 'hegemony' reflects a specific way in which emerging capitalist class power since the sixteenth century, located in a particular territorial state, expands its reach outwards in an effort to place its metropole, its national customs and values, at the centre of a system of global capitalist accumulation (Wallerstein 2011b, pp. xxii-xxvii). Understood in a sense that builds on the work of Antonio Gramsci, political, juridical and military power of the state is used then by capitalist elites to attempt to normatively encourage, lead, control and direct the flow of capital within a growing capitalist world economy (Gramsci 1971; Cox 1983).

Periods of Dutch hegemony in the early seventeenth century, British hegemony in the nineteenth century and US hegemony in the middle to latter part of the twentieth have each relied upon the universalisation of a natural rights discourse to present a juridical idea of lawful international relations in which the ideas of commerce and peace are understood as mutually reinforcing. In the later twentieth and early twenty-first centuries the expression of US hegemonic power has involved the use of the techniques of 'exception' and 'security', as well as the governance technique of openness/closure which has involved the promotion of 'universal', liberal human rights and private property rights in some instances, and their suspension and suppression in others. In maintaining a link between commerce and peace US hegemonic power has relied upon a technique of attempting to coordinate the interests and minimise conflict between American capitalist classes and a transnational capitalist class. In this, the juridical language of natural rights has performed a leading role in helping to normatively coordinate and propagate logics of private property and the 'self-regulating market'. Further, the USA has attempted to pacify global commerce via violently disciplining through war and debt restructuring (as 'economic warfare') opponents to its development model.

Via moral and political leadership of the liberal world order the USA, through the Cold War and in its wake, has utilised the juridical language and institutions of international law in an effort to maintain control of the lines of global capital accumulation and see off both its socialist and capitalist rivals. However, US industrial predominance has declined since the 1970s, and a shift to a reliance upon finance capital (Arrighi 1994; Harvey 2011) and military power to maintain global influence have both suffered forms of 'crises' in the twenty-first century. The 2008 financial crisis and subsequent neoliberal recession, and inability to control Russian aggression in Ukraine and Crimea (2014-) or successfully complete its violent acts of regime change in Afghanistan (2001-), Iraq (2003-), and Syria (2014-), have left open the question of how long, and in what ways, the US can continue to exert power over the global world system. ${ }^{9}$ The question remains open also as to whether and to what extent a natural rights-based conceptual structure of liberal international

\footnotetext{
${ }^{8}$ For various accounts see Schmitt (2003), Grewe (2000), Simpson (2009).

9 The attempted creation of the 'Transatlantic Trade and Investment Partnership' and 'Trans-Pacific Partnership' free trade treaties can be interpreted as an effort by US capital to regain some degree of control over the global economy.
} 
law can continue as a 'universal' juridical form if a slow decline of American economic hegemony, and decline in economic fortunes of Anglophone and Western European liberal states, were to continue. ${ }^{10}$

Highlighting such a set of links in the twentieth and twenty-first centuries between state hegemony, capitalist accumulation and natural rights does not completely reduce the discourse of liberal international law to the mere handmaiden of US-centred capitalist class and state power. Both the institutional structures of twentieth and twenty-first-century international law, and the discourse of international law itself, operate not simply as a modern capitalist ideological formation, but occur also as a site of contestation over the nature and precise content of competing visions of social and economic justice.

In varieties of Soviet international jurisprudence and in the concept of 'selfdetermination' the language of international law has been used to provide both radical and totalitarian alternative conceptualisations of what twentieth-century international law could have been (Bowring 2008). As postcolonial and third world' approaches to the theorisation of international law point out, both the language of international law (in terms of human rights, self-determination, sovereignty) and institutions of various UN agencies have played an important role in pushing back against American hegemonic power and in imagining alternative forms of a possible international law of the future (Anghie 2005; Rajagopal 2003; Barreto 2013). While the various histories of postcolonial counter-hegemonic contestation over the nature of international law have not always been successful, their radical emancipatory heritage speaks still as much to the future of international law, and the nature of 'development', as it does to the past. Further, the natural rights language that underpins modern international law is continually mobilised both in the West and in the developing world as a form of 'immanent critique' against the co-option of the language of international law by US hegemonic power (Marks 2000). Also, against an idea of international law controlled and constrained by US power, liberal cosmopolitans draw upon a natural rights language to project a utopian idea of a future, cosmopolitan international law which attempts to restrain capital by globalising the redistributive principles contained within the idea of the welfare state and social democracy (Habermas 2012; Pogge 2008).

Such a sense of understanding the language and institutions of modern international law as a site of hegemonic and counter-hegemonic contestation is given by Koskenniemi (2011a, pp. 219-240). In this, the language and institutional life of international law is conceived as a discursive battleground in which the 'indeterminacy' of linguistic meaning is subject to the endless manipulation of competing and shifting political claims (Koskenniemi 2006; Kennedy 1987). Such a conceptualisation channels an understanding of the relationship between law, linguistic meaning and political power found not only in American 'legal realism', the post-structural theories of Derrida (1978) and Lyotard (1984), and the postMarxist theory of Laclau and Mouffe (2001), but echoes an older conception of the

\footnotetext{
10 The question of what role non-Anglophone and non-European conceptions of global legality will play in the future with the rise of economic, political and military power in parts of the former 'developing world' is a crucial question. The question is however beyond the scope of this essay.
} 
relationship between law, political power and rhetoric found in the writings of Machiavelli (Machiavelli 1996; Pocock 2003) and in the ancient Sophists (Bloch 1996, pp. 10-16). Viewed in this light, law and international law, remain a potentially open field through which political, social and economic counterhegemonic claims can be channelled against the attempt by capitalist hegemonic power to close down, discipline and control categories of legal meaning. As such, alternative discourses and sources of regional and global legal imagination offer rival utopian visions to the discourse of liberal international law. These open onto the possibility of using the language of international law to critique and possibly recalibrate the relationship between capitalist accumulation, state hegemony and natural rights thinking.

One danger however of focussing too specifically upon the 'indeterminate' nature of liberal international law is to sometimes over-emphasise linguistic and conceptual dispute and rhetorical strategy at the expense of historical and political context. Another danger is to reduce critical analysis to a version of 'realist' international relations theory in which a discourse of liberal international law is understood primarily within a framework of the endless struggle for power between rival states. Against these tendencies it is worth gently reframing Koskenniemi's notion of hegemonic and counter-hegemonic conflict within international law as primarily a juridical question of ongoing social and economic contestation over the idea of justice. In this respect, rather than viewing the problem of international law as of one of linguistic indeterminacy, the problem is one of a range of conflicting and competing normative claims between rival class, state and other non-state political groupings who draw upon a universal language of international law to help express, and politically realise (sometimes through violence), alternate conceptions of social and economic justice.

In modernity, from the seventeenth century the dominant outcome of this contest within the discourse of international law has been the idea of 'liberal international law' whose structure has built upon a relationship between natural rights thinking, capitalist accumulation, and state hegemony. This form of global juridical order has been created and sustained through violence and has been subject to endless forms of counter-hegemonic contestation from both within the developing world and within the West. In the early twenty-first century this juridical form of the liberal world order is still dominant, though it is now sitting somewhat precariously.

The central importance of framing the discourse of international law as a site of contestation over questions of social and economic justice comes into a sharper light when placed in contrast to the Marxist commodity-form theory of international law developed by Evgeny Pashukanis and popularised by China Miéville. Pashukanis linked the natural rights theory and international legal theory of Grotius to the conceptual structure of 'commodification' contained within emerging sixteenth- and seventeenth-century capitalist relations of production and exchange. On this account the 'universal' language of natural rights is read as a legal vehicle of expansionist capitalist class power and 'bourgeois' economic freedom (Pashukanis 1978, pp. 96, 114-129, 136-144; 2006, pp. 329-334). Liberal international law, as natural rights thinking, justifies a modern form of ever-expanding capitalist imperialism 
(Pashukanis 2006, pp. 329-334; Miéville 2006, pp. 225-230, 268-271, 291-293, 316-319).

While there is much to praise within Pashukanis' critical account, one key problem is that the commodity-form theory of law reduces all lawful relations to an expression of economic relations. In this, law is always the mere 'superstructural' expression of a supposed economic 'base' and hence the discourse of international law is viewed as equalling only 'imperialism'. One result is that the categories of law and international law are then exhausted of any emancipatory potential. 'Law' and 'international law' can only ever constitute a form of bourgeois, capitalist, imperialist, domination.

However, the elements of economic determinism within the commodity-form theory of law overlook the very juridical nature of economic and political struggles. Aspects of such a critique have been made forcefully by both Bowring (2008, pp. 9-39) and Pal (2012). What is worth highlighting further is the way in which an economic reductionist theory of law misses a key aspect of juridical relations in which law is not merely a form of economic domination, but serves also as a framework of emancipatory imagination and struggle when expressing an alternative vision of social and economic justice. This form of thinking involves the sense of understanding law (as nomos, as dike, as recht, as right, as justice) as an expression of a 'concrete universal' where the dignity and social being of a community is realised through the creation of legal and political institutions. In this, the counter-hegemonic legal claim condemns the domination of a particular historical, legal regime in the name of an idea of justice, human dignity, or equality, which is 'not yet' and 'yet to come'. Such a theorisation of law has been developed by Ernst Bloch in relation to the natural law and natural rights tradition (Bloch 1996), by Costas Douzinas in relation to the human rights tradition (Douzinas 2000), and by Jacques Derrida in relation to the idea of global justice and international law (Derrida 1994). An aspect of this emancipatory account of international law is expressed also by Boaventura de Sousa Santos, particularly in the way in which non-Western legal and normative categories can play a key role in re-framing a global politics of emancipation (De Sousa Santos 2002).

This reading of the natural law tradition can be situated alongside a radical republican constitutional tradition which understands legal-constitutional discourse as involving agonistic claims of the demos against its economic domination by a ruling class through a historical legal order. In this, the potential creation of a new constitutional order via law operates as the expression of an alternative juridical vision of social and economic justice. Further, this line of thinking sees the legal, political and economic aspects of the constitution as intrinsically linked, and as such, the perpetual agonistic and antagonistic nature of constitutional struggle can operate to constantly address and redress questions of economic injustice, inequality and exclusion. In the ancient world, Greek and Roman constitutional struggles over constitutional participation, inequality, corruption and the agrarian law express this very juridical sense of political and economic class struggle (Polybius 2010; Finley 1999; Brunt 1971; Anderson 1996). In modern radical republican theory, found in the work of Machiavelli (1996) and Negri (1999), the idea of 'constituent power' expresses a form of struggle over the very legal nature of political and economic 
justice. ${ }^{11}$ In a less radical sense, as described by Wolgang Streeck, an aspect of this republican constitutional tradition expresses itself also in the attempt by the welfare state in Europe in the twentieth century to democratically restrain capitalism (Streeck 2014).

Reading the radical natural law and radical republican constitutional traditions together helps to offer a framework of thinking about a variety of counterhegemonic legal claims within the discourse of twentieth- and twenty-first-century international law. Generally a number of such counter-hegemonic claims might be seen to range from socialist and anti-colonial revolutions, wars of national liberation, the politics of self-determination, the idea of a 'new international economic order', the global language of social and economic rights, indigenous rights, the 'world social forum', the environmental idea of the 'global commons', and the various forms of 'occupy' and anti-austerity social movements. In this respect, while the conceptual structure of liberal international law, built around capitalist accumulation, natural rights and state hegemony, expresses a very violent form of global domination, it does not necessarily exhaust the emancipatory potential of the discourse of international law.

Further, one way of thinking about the emancipatory potential of international law is to remember the history of the natural law and natural rights traditions as involving debates over the nature of 'property' and its relation to human dignity and justice. Pashukanis, like McPherson (1962), was certainly correct to note that a version of seventeenth-century natural rights, as an ideological form, gave normative expression to the interests of emerging capitalist classes in parts of Western Europe. Yet, as pointed out by Ernst Bloch, the existence of a bourgeois natural rights discourse does not exhaust the emancipatory potential of a whole set of historical and futural natural law and natural rights theories which condemn private property in the name of dignity, equality or justice (Bloch 1996, pp. 181-208). A variety of natural law and natural rights concepts stretching from Zeno, to radical Franciscans, to Gerrard Winstanley, to Jean-Jacques Rousseau through to Karl Marx offer a radical heritage of legal categories aimed at critiquing and resisting commodification and are therefore relevant to counter-hegemonic discourses of international law.

Further, thinking about the post-1945 international legal order in a 'global constitutional' sense opens onto conceptualising modern international law in terms of the heritage of the radical republican constitutional tradition. Certainly the dominant form of transnational legal constitutionalism today is that described by Slaughter (2005) and Teubner (2012), each with varying degrees of celebration of the 'autonomous' logic of global neoliberal, capitalist relations, tempered by minor interventions from global 'civil society'. Yet such a framework does not exclude us from thinking about how agonistic constitutional and class politics, and ideas of constituent power can be used as intellectual resources to rethink the idea of global constitutionalism. In this mode of thinking, law, as a constitutional form, contains emancipatory potential which is not exhausted by either seventeenth-century

\footnotetext{
11 See also the accounts in Rancière (2004), Christodoulidis (2009), Wall (2011), Schaap (2009).
} 
bourgeois natural rights, or by early twenty-first-century forms of neoliberal transnational constitutionalism. ${ }^{12}$

When thought of as a modern heritage of the radical natural law and radical republican constitutional traditions, the modern discourse of international law continues to hold weight as an emancipatory discourse. When framed as a public discourse of social equality, human dignity, social justice, and as the potential grounds from which democratic constitutionalism might one day regulate, re-embed or even abolish entirely capitalist markets, then an idea of international law offers a utopian dream, but not one of a liberal-capitalist variety. The aim of such a suggestion is not to romanticise the discourse of international law, but merely to point to an alternative intellectual heritage of modern international law which is often overlooked or not remembered. Such a radical underside of liberal international law opens a space for legal and political contestation, and holds onto the idea that juridical concepts of social justice and human dignity may help to guide, steer and control economic relations in the future.

Acknowledgments This article was written with assistance of a period of research leave funded by The Leverhulme Trust. Thanks to Kenny Veitch, Jo Bridgeman and Alex Conte as well as to the anonymous reviewers for their comments on earlier drafts of this paper.

Open Access This article is distributed under the terms of the Creative Commons Attribution 4.0 International License (http://creativecommons.org/licenses/by/4.0/), which permits unrestricted use, distribution, and reproduction in any medium, provided you give appropriate credit to the original author(s) and the source, provide a link to the Creative Commons license, and indicate if changes were made.

\section{References}

Agamben, Giorgio. 1998. Homo Sacer (trans. Heller-Roazen, Daniel). Stanford: Stanford University Press.

Amin, Samir. 1997. Capitalism in the age of globalisation. London: Zed Books.

Anderson, Perry. 1996. Passages from antiquity to feudalism. London: Verso.

Anderson, Perry. 2013. Imperium. New Left Review. 83: 5-111.

Anghie, Anthony. 2005. Imperialism, sovereignty and the making of international law. Cambridge: Cambridge University Press.

Aristotle, 2001. Politics. In The basic works of Aristotle, ed. Richard McKeon. New York: Modern Library.

Armitage, David. 2000. The ideological origins of the British Empire. Cambridge: Cambridge University Press.

Arrighi, Giovanni. 1994. The long twentieth century. London: Verso.

Arrighi, Giovanni. 2007. Adam Smith in Beijing. New York: Verso.

Barreto, Jose-Manuel (ed.). 2013. Human rights from a third world perspective: Critique, history and international law. Newcastle: Cambridge Scholars Publishing.

Bentham, Jeremy. 1843. Principles of international law. In The works of Jeremy Bentham, vol. 2, ed. J. Bowring. Edinburgh: William Tait.

Bloch, Ernst. 1996 Natural law and human dignity (trans. Schmidt, Dennis). Cambridge: M.I.T. Press.

Block, Fred. 1977. The origins of international economic disorder. Berkeley: University of California Press.

12 One sense of thinking about global constitutionalism is given in Hardt and Negri (2009). 
Bohman, James, and Matthias Lutz-Bachman (eds.). 1997. Perpetual peace: Essays on Kant's cosmopolitan ideal. Cambridge: MIT Press.

Bowring, Bill. 2008. The degradation of the international order? The rehabilitation of law and the possibility of politics. Abingdon: Routledge-Cavendish.

Braudel, Fernand. 1984. Civilisation and capitalism 15th-18th century, Vol. 3: The perspective of the world (trans. Reynolds, Sian). London: Fontan Press.

Brenner, Robert. 2006. The economics of global turbulence. London: Verso.

Brunt, P.A. 1971. Social conflicts in the Roman Republic. New York: Norton.

Brunt, P.A. 2013. Studies in stoicism. Ed. Miriam Griffin and Alison Samuels. Oxford: Oxford University Press.

Butler, Judith. 2010. Frames of war: When is life grievable?. New York: Verso.

Chang, Ha-Joon. 2003. Kicking away the ladder: Development strategy in historical perspective. London: Anthem Press.

Chimni, B.S. 2004. International institutions today: An imperial global state in the making. European Journal of International Law 15(1): 1-37.

Chimni, B.S. 2006. Third world approaches to international law: Manifesto. International Community Law Review 8: 3-27.

Chomsky, Noam. 1991. Deterring democracy. London: Verso.

Christodoulidis, Emilios. 2009. Strategies of rupture. Law and Critique 20(1): 3-26.

Cicero. 1991. On duties. Ed. M. Griffin and E. Atkins. Cambridge: Cambridge University Press.

Cox, Robert. 1983. Gramsci, hegemony and international relations: An essay in method. Millenium 12(2): $162-175$.

De Sousa Santos, Boaventura. 2002. Toward a new legal common sense: Law, globalization, and emancipation. London: Butterworths.

Derrida, Jacques. 1978. Violence and metaphysics: An essay on the thought of Emmanuel Levinas. In Writing and difference (trans. Bass, A.). Chicago: University of Chicago Press.

Derrida, Jacques. 1994. Specters of Marx: The state of debt, the work of mourning and the new international (trans. Kamuf, Peggy). New York: Routledge.

Dillon, Michael, and Julien Reid. 2009. The liberal way of war. London: Routledge.

Dorsett, Shaunnagh, and Shaun McVeigh. 2012. Jurisdiction. Abingdon: Routledge.

Douzinas, Costas. 2000. The end of human rights: Critical legal thought at the turn of the century. Oxford: Hart.

Douzinas, Costas. 2007. Human rights and empire: The political philosophy of cosmopolitanism. Abingdon: Routledge-Cavendish.

Doyle, Michael. 1983. Kant, liberal legacies, and foreign affairs. Philosophy \& Public Affairs 12(3): 205-235.

Erskine, Andrew. 2011. The Hellenistic stoa, 2nd ed. Bristol: Bristol Classics Press.

Fine, Robert. 2007. Cosmopolitanism. London: Routledge.

Finley, M.I. 1999. The ancient economy. Berkeley: University of California Press.

Garnsey, Peter. 2007. Thinking about property. Cambridge: Cambridge University Press.

Gilpin, Robert. 2001. Global political economy. Princeton: Princeton University Press.

Gramsci, Antonio. 1971. Selections from the prison notebooks. Ed. Q. Hoare and G. Nowell-Smith. London: Lawrence \& Wishart.

Grewe, Wilhelm. 2000. The epochs of international law (trans. Byers, Michael). Berlin: Walter de Gruyer.

Grotius, Hugo. 2004. The free sea. Ed. David Armitage, trans. Richard Hakluyt. Indianapolis: Liberty Fund.

Grotius, Hugo. 2005. The rights of war and peace. Ed. Richard Tuck. Indianapolis: Liberty Fund.

Haakonssen, Knud. 1996. Natural law and moral philosophy: From Grotius to the Scottish enlightenment. Cambridge: Cambridge University Press.

Habermas, Jurgen. 2012. The crisis of the European Union in light of the constitutionalization of international law. European Journal of International Law 23(2): 335-348.

Hardt, Michael, and Antonio Negri. 2001. Empire. Cambridge: Harvard University Press.

Hardt, Michael, and Antonio Negri. 2009. Commonwealth. Cambridge: Harvard University Press.

Harvey, David. 2011. The enigma of capital. London: Profile Books.

Held, David. 1995. Democracy and the global order: From the modern state to cosmopolitan governance. Cambridge: Polity Press. 
Hill, Lisa. 2010. Adam Smith's cosmopolitanism: The expanding circles of commercial strangership. History of Political Thought 31(3): 449-473.

Hobsbawm, Eric. 1977. The age of revolution 1789-1848. London: Abacus.

Hobsbawm, Eric. 1994. The age of empire 1875-1914. London: Abacus.

Hobsbawm, Eric. 1997. The age of capital 1848-1875. London: Abacus.

Hobson, J.A. 2011. Imperialism: A study. Ed. N. Mehr. London: Spokesman Books.

Hont, Istvan. 2005. Jealousy of trade. Cambridge: Harvard University Press.

Hume, David. 1994. 'Of commerce' and 'jealousy of trade'. In Political essays, ed. Knud Haakonssen. Cambridge: Cambridge University Press.

Ikenberry, John G. 2012. Liberal Leviathan: The origins, crisis and transformation of the American world order. Princeton: Princeton University Press.

Ittersum, Van, and Martine Julia. 2006. Profit and principle: Hugo Grotius, natural rights theories and the rise of Dutch power in the East Indies 1595-1615. Leiden: Brill.

Jahn, Beathe. 2013. Liberal internationalism: Theory, history, practice. Basingstoke: Palgrave Macmillan.

Jolowicz, H.F., and Barry Nichols. 1972. Historical introduction to the study of Roman law, 3rd ed. Cambridge: Cambridge University Press.

Kant, Immanuel. 1991. Perpetual peace: A philosophical sketch, and, idea for a universal history with a cosmopolitan purpose. In Political writings, ed. H.I. Reiss. Cambridge: Cambridge University Press.

Kennedy, David. 1987. The sources of international law. American University Journal of International Law and Policy 2(1): 1-96.

Kennedy, Paul. 2006. The parliament of man. London: Penguin Books.

Kingsbury, Benedict, and Benjamin Straumann. 2010. The state of nature and commercial sociability in early modern international legal thought. Grotiana 31(22): 22-43.

Kochi, Tarik. 2009. The other's war: Recognition and the violence of ethics. Abingdon: Birkbeck Law Press.

Koskenniemi, Martti. 2006. From apology to Utopia: The structure of international legal argument. Cambridge: Cambridge University Press.

Koskenniemi, Martti. 2011a. The politics of international law. Oxford: Hart.

Koskenniemi, Martti. 2011b. Empire and international law: The real Spanish contribution. University of Toronto Law Journal 61: 1-36.

Laclau, Ernesto, and Chantal Mouffe. 2001. Hegemony and socialist strategy, 2nd ed. London: Verso.

Lenin, V.I. 1987. Imperialism, the highest stage of capitalism, and, The state and revolution. In Essential works of Lenin, ed. H.M. Christman. New York: Dover.

Locke, John. 1988. Two treatises of government. Ed. Peter Laslett. Cambridge: Cambridge University Press.

Lyotard, Jean-François. 1984. The postmodern condition (trans. Bennington, Geoffrey). Manchester: Manchester University Press.

Machiavelli, Niccolò. 1996. Discourses on Livy (trans. Mansfield, H. and Tarcov, N.). Chicago: University of Chicago Press.

Macpherson, C.B. 1962. The political theory of possessive individualism. Oxford: Oxford University Press.

Mann, Michael. 2013. The sources of social power, Vol 4: Globalizations, 1945-2011. Cambridge: Cambridge University Press.

Marks, Susan. 2000. The riddle of all constitutions. Cambridge: Cambridge University Press.

Marx, Karl. 1990. Capital, vol. 1 (trans. Fowkes, Ben). London: Penguin.

McCormick, Thomas. 1995. America's half-century. Baltimore: Johns Hopkins University Press.

Miéville, China. 2006. Between equal rights: A Marxist theory of international law. London: Pluto Press.

Negri, Antonio. 1999. Insurgencies (trans. Bosxagli, M.). Minneapolis: University of Minnesota Press.

Neocleous, Mark. 2008. Critique of security. Edinburgh: Edinburgh University Press.

Neocleous, Mark. 2014. War power, police power. Edinburgh: Edinburgh University Press.

Nussbaum, Martha. 2002. For love of country. New York: Beacon Press.

Orford, Anne. 2007. Reading humanitarian intervention: Human rights and the use of force in international law. Cambridge: Cambridge University Press.

Pahuja, Sundhya. 2011. Decolonising international law: Development, economic growth and the politics of universality. Cambridge: Cambridge University Press.

Pal, Maia. 2012. The politics of extraterritoriality: A historical sociology of public international law. $\mathrm{PhD}$ thesis, University Sussex. 
Pashukanis, Evgeny. 1978. Law and Marxism: A general theory. Ed. Chris Arthur, trans. Barbara Einhorn. London: Links.

Pashukanis, Evgeny. 2006. International law. In Between equal rights: A Marxist theory of international law, ed. China Miéville. London: Pluto Press.

Peet, Richard. 2009. Unholy Trinity: The IMF, World Bank and WTO, 2nd ed. London: Zed Books.

Pocock, J.G.A. 2003. The Machiavellian moment: Florentine political thought and the Atlantic Republican tradition. Princeton: Princeton University Press.

Pogge, Thomas. 2008. World poverty and human rights: Cosmopolitan responsibilities and reforms. Cambridge: Polity Press.

Polanyi, Karl. 2001. The great transformation. Boston: Beacon Press.

Polybius. 2010. The histories (trans. Waterfield, Robin). Oxford: Oxford University Press.

Pufendorf, Samuel. 2003. The whole duty of man according to the law of nature. Ed. Ian Hunter and David Saunders. Indianapolis: Liberty Fund.

Rajagopal, Balakrishnan. 2003. International law from below. Cambridge: Cambridge University Press. Rancière, Jacques. 2004. Disagreement (trans. Rose, Julie). Minneapolis; Minnesota University Press.

Rawls, John. 1993. The law of peoples. Cambridge: Harvard University Press.

Rist, Gibert. 2014. The history of development. New York: Zed Books.

Robinson, William. 1996. Promoting polyarchy: Globalization, US intervention, and hegemony. Cambridge: Cambridge University Press.

Robinson, William. 2014. Global capitalism and the crisis of humanity. Cambridge: Cambridge University Press.

Said, Edward. 1978. Orientalism. New York: Pantheon Books

Schaap, Andrew (ed.). 2009. Law and agonistic politics. Abingdon: Routledge.

Schmitt, Carl. 2003. The nomos of the earth (trans. Ulmen, G.L.). New York: Telos Press.

Selden, John. 1652. Of the dominion, or ownership of the sea (trans. Nedham, Marchamont) (New Exchange: William Du-Gard).

Simpson, Gerry. 2009. Great powers and outlaw states. Cambridge: Cambridge University Press.

Slaughter, Anne-Marie. 2005. A new world order. Princeton: Princeton University Press.

Smith, Adam. 1999a. The wealth of nations, vol. 1, Ed. Andrew Skinner. London: Penguin.

Smith, Adam. 1999b. The wealth of nations, vol. 2. Ed. Andrew Skinner. London: Penguin.

Smith, Adam. 2007. The theory of moral sentiments. Ed. Knud Haakonssen. Cambridge: Cambridge University Press.

Somos, Mark. 2011. Secularisation and the Leiden circle. Leiden: Brill.

Somos, Mark. 2012. Selden's Mare Clausum: The secularisation of international law and the rise of soft imperialism. Journal of the History of International Law 14(2): 287-330.

Streeck, Wolgang. 2014. Buying time: The delayed crisis of democratic capitalism (trans. Camiller, P.). London: Verso.

Teubner, Gunter. 2012. Constitutional fragments. Oxford: Oxford University Press.

Tierney, Brian. 2001. The idea of natural rights. Grand Rapids: Eerdmans Publishing.

Tuck, Richard. 1981. Natural rights theories: Their origin and development. Cambridge: Cambridge University Press.

Tuck, Richard. 1993. Philosophy and government 1572-1651. Cambridge: Cambridge University Press.

Tuck, Richard. 1999. The rights of war and peace: Political thought and the international order from Grotius to Kant. Oxford: Oxford University Press.

Villey, Michel. 2000. Epitome of classical natural law (Part 1), trans. G. Voilley. Griffith Law Review 9(1): 74-97.

Vitoria, Francisco. 1991. On the American Indians. In Political writings, ed. A. Padgen, and J. Lawrance. Cambridge: Cambridge University Press.

Wall, Illan Rua. 2011. Human rights and constituent power. Abingdon: Routledge.

Wallerstein, Immanuel. 2004. World systems analysis: An introduction. Durham: Duke University Press.

Wallerstein, Immanuel. 2011a. The modern world system, vol. 1: Capitalist agriculture and the origins of the European world-economy in the sixteenth century. Berkeley: University of California Press.

Wallerstein, Immanuel. 2011b. The modern world system, vol. 2: Mercantilism and the consolidation of the European world-economy, 1600-1750. Berkeley: University of California Press.

Westad, Odd Arne. 2007. The global cold war. Cambridge: Cambridge University Press.

Wyatt-Walter, Andrew. 1996. Adam Smith and the liberal tradition in international relations. Review of International Studies 22(1): 5-28. 